\title{
Etäkoulu on digitaalisuuden interventio
}

Suomalaisten opettajien ja koulujen nopeutta etäopetukseen siirtymisessä on ihasteltu ja hämmästelty. Ensiluokkalaisista lähtien oppilaat osallistuvat nyt videovälitteisiin luokan tapaamisiin ja digitaalisia välineitä hyödynnetään monipuolisesti opiskelussa kotona. Digitaaliset välineet ovat tulleet kouluihin pikkuhiljaa hiipien. Välineisiin on tutustuttu ja sekä opettajat että oppilaat ovat saaneet valmiuksia välineiden käyttöön luottaen opettajien pedagogiseen ammattitaitoon. Opettajat ovat voineet tutustua digitaalisiin välineisiin pedagogisesti ja ainedidaktisesti harkiten, miten välineet parhaiten tukisivat opetussuunnitelman tavoitteiden saavuttamista.

Etäkoulun järjestämisessä herää ensin kysymyksiä opettajan näkökulmasta: Miten opettaja saa annettua tehtävät ja miten uusi asia esitellään oppilaille? Miten opettaja saa tietoa siitä, että opiskeleeko oppilas, miten opettaja saa tietoa oppilaan oppimisesta ja miten opettaja antaa palautetta oppilaalle? Wilma ja muut managerointivälineet ovat vastanneet moniin ylläolevista kysymyksistä.

Kun opetuksen perusasiat on saatu toimimaan, voidaan miettiä sitä, kuinka etäopetuksessa voidaan tukea perusopetuslain mukaisesti "oppilaiden kasvua ihmisyyteen ja eettisesti vastuukykyiseen yhteiskunnan jäsenyyteen". Tässä olennaista lienee opiskelu yhdessä digitaalisissa ympäristöissä: Miten oppilaat jakavat ajatuksiaan? Miten oppilaat työstävät yhteisiä dokumentteja? Entä miten opiskelusta tulee oppilaiden yhteisöllistä kohteellista toimintaa?

Kun kouluissa palataan jälleen normaaliin arkeen, ovat oppilaat ja opettajat kenties valmiimpia digitaalisten välineiden uudenlaiseen käyttöön, missä korostuu yhteisöllinen uutta luova toiminta.

Kalle Juuti, Seija Kairavuori ja Arto Kallioniemi

Helsingin yliopisto, Kasvatustieteellinen tiedekunta 